\title{
Hair cycle in dogs with different hair types in a tropical region of Brazil
}

\section{Evandro S. Favarato and Lissandro Gonçalves Conceição}

Dermatology and Internal Medicine, Departamento de Veterinaria, Universidade Federal de Vicosa, Campus Universitario s/n, Vicosa Minas Gerais, Brazil 36570-000

Correspondence: Lissandro Goncalves Conceicao, Dermatology and Internal Medicine, Departamento de Veterinaria, Universidade Federal de Vicosa, Campus Universitario s/n, Vicosa, Minas Gerais, Brazil 36570-000. E-mail: lissandro@ufv.br

What is known about the topic of this paper

- To the authors knowledge canine hair follicle cycle has not been studied in a tropical climate.

- Previous studies on canine hair cycle were done in a temperate climate.

- Canine hair cycle suffered more influence from the photoperiod than temperature.

What this paper adds to the field of veterinary dermatology

- In a tropical region, canine hair cycle of Boxer and Labrador dogs was influenced by both photoperiod and temperature.

- In Boxer and Labrador telogen hairs predominated in the hottest months, and anagen hairs predominated in the coldest months.

- Schanauzer dogs showed no differences in the percentage of telogen or anagen hairs during the one year period of study.

\begin{abstract}
Hair cycle activity has been extensively studied in humans, sheep and laboratory animals, but there is a lack of information in dogs. Besides varying according to species, breed, sex and general health, hair growth is mainly affected by climatic variations. The aim of the study was to evaluate the follicle activity in three breeds of dogs with different hair types, in the city of Viçosa, Minas Gerais (latitude $20^{\circ} 45^{\prime}$ S), Brazil. Twentyone male dogs of boxer, labrador and schnauzer breeds were trichographically analysed monthly over 12 consecutive months. Hair percentage of telogen and anagen hairs at the different stages of the hair cycle in boxers and labradors was not significantly different, but both differed from the schnauzers. A significant correlation between hair follicle cycle and environmental temperature and photoperiod was noted in the boxers and labradors. In these breeds, a larger number of telogen hairs were observed during the hottest months of the year, and an increase in anagen hairs during the coldest months. The mean percentage of telogen hairs was
\end{abstract}

93, 90 and $55.3 \%$ for boxer, labrador and schnauzer, respectively.

Accepted 10 October 2007

\section{Introduction}

Mammalian hairs are skin appendages important for thermal regulation, sensory perception and as a barrier against various aggressions. ${ }^{1}$ They are slender flexible structures produced by hair follicles and have two separate parts, a free portion, the shaft, and an intradermal root. ${ }^{2-4}$

Hairs do not grow continually, but in follicle cycles ${ }^{1,5-8}$ each of which consists of a growth period (anagen during which the follicle is producing the hair), a rest period (telogen with cessation of growth and retention in the hair follicle), and in dogs, a period of hair elimination to the environment (exogen) to be replaced then by a new growing hair (anagen). There is also an important regenerative and transition phase (catagen) between the anagen and telogen periods. ${ }^{1,5,6,8,9}$ The duration of each phase varies according to species, breed, age, sex, and body area and can be modified by a variety of physiological and pathological factors. ${ }^{1,6,10}$ The follicular cyclic activity that allows pelage adaptation to seasonal environmental variations is mainly influenced by photoperiod and to a smaller degree by variations in environmental temperature., ${ }^{1,6}$

The photoperiod and environmental temperature fluctuations may act on the pineal gland, hypothalamus and hypophysis, modifying the levels of several hormones that directly influence the cyclic activity of the hair follicles. ${ }^{1,9}$ Among these, melatonin and prolactin modulate hair growth through still unknown mechanisms of action. ${ }^{11}$ Melatonin seems to have an indirect action on the hair cycle, via regulation of prolactin secretion by the hypophysis. ${ }^{12}$

In view of the lack of information on the behaviour of the canine hair cycle in the tropics, the aim was to evaluate the cycle over the period of 1 year in three breeds of dogs with different pelage, in the city of Viçosa, Minas Gerais, (latitude $20^{\circ} 45^{\prime} \mathrm{S}$ - tropical climate), Brazil.

\section{Materials and methods}

\section{Animals}

A total of 21 dogs, from breeds with pelages of different lengths and commonly found in Viçosa, were classed into three groups according to hair type namely BG: a short-hair coat type consisting of six boxers; LG: a medium-length-hair coat type consisting of eight labradors; and SG: a long-hair coat type consisting of seven schnauzers.

These were healthy, vaccinated and dewormed dogs, aged 1-5 years, domiciled in the city, and received complete physical and dermatological 
examinations monthly throughout the entire observation period. To eliminate the possible influence of the oestrus cycle on the hair cycle, only intact male dogs were used, according to methodology already described, ${ }^{13}$ because high levels of oestrogens may suppress the anagen phase. ${ }^{1}$ All dogs had already been receiving adult maintenance diets produced by multinational companies and widely sold in the Brazilian market, and as these had similar formulations, the owners were requested to maintain the same diet during the entire study period. In addition, all the animals were kept outdoors and, therefore, exposed to similar influences of photoperiod and ambient environmental temperature.

The research programme was approved by the Ethics Commission of the Veterinary Department of the Federal University of Viçosa, August 2005 (Protocol number 43/2005). Owner agreement for inclusion of their dogs was obtained in all instances.

All the participants remained healthy during the entire observation period. No animal received any medicine that could potentially influence the hair cycle, inducing anagen or telogen phases. ${ }^{9}$

\section{Hair sample collection}

Hair samples were collected from the shoulder region of each animal every 30 days over a year (July 2005 to late June 2006) with alternation of the side every month. The area selected for depilation on the subsequent month was close to but not within the previous site. The shoulder was chosen because it showed the lowest variation in the number of telogen and anagen hairs in a previous study. ${ }^{5}$ The areas were depilated using haemostatic tweezers, with the indented part coated with rubber to avoid damaging the hair shaft. A small tuft of hair was clasped within the tweezers, and the hairs were pulled out simultaneously with a rapid movement, creating a small area of visible hypotrichosis. To minimize the risk of breaking the hair root within the follicle, the depilation movement always followed the direction of hair growth. Immediately after collection, the hairs were stored in clean flasks and microscopically analysed.

\section{Trichogram examination}

Trichogram evaluation was chosen to analyse and interpret the hair cycle, because besides being a simple and noninvasive technique, it accurately differentiates between the phases. ${ }^{14}$ Some researchers have used the unit area trichogram method to analyse the canine hair cycle, ${ }^{5,9}$ but this required the use of general anaesthesia. In this study, the hair collection (a total of 12 samples per animal) was carried out at the owner's residence.

Glass microscopy slides were prepared by previously sticking a double-faced adhesive tape on the upper surface $(25.4 \times 76.2 \mathrm{~mm})$ in a longitudinal direction. The collected hairs were positioned separately in parallel, perpendicular to the tape surface (Fig. 1), to facilitate hair bulb analyses.

The hairs were evaluated by light microscopy at magnifications of $\times 40$ and $\times 100$ following previously defined criteria and classed as anagen or telogen by the appearance of bulbs. ${ }^{5,9,14}$ Hairs were considered to be in the anagen phase when the bulbs appeared round, flat, shiny, frequently curved and sometimes pigmented, and were considered to be in the telogen phase when they appeared claviform, wrinkly, nonpigmented and generally rectilinear. Since catagen hair roots are morphologically similar to telogen roots, hairs suspected of being in the catagen phase were classed as telogen. 5,9 The percentage of hairs in each phase was determined by classifying the bulbs of the first 100 hairs with whole roots, ${ }^{14}$ always counting from right to left of the glass slide. An additional count was similarly undertaken to determine the percentage of damaged hairs, i.e. those with a broken

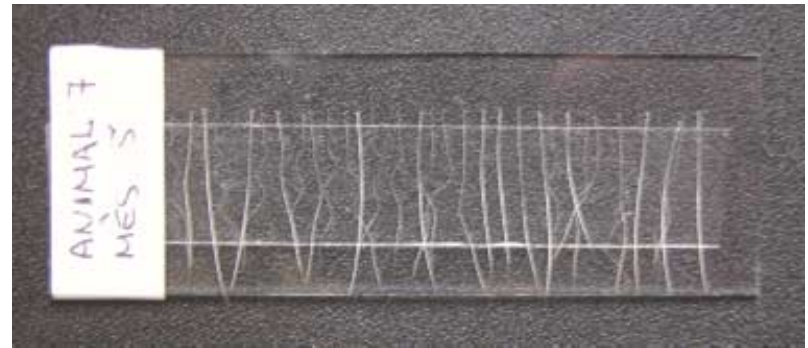

Figure 1. Mounting of hairs on the slide. The hairs were arranged parallel to each other and perpendicular to the length of the doublesided adhesive strip, placed previously on a glass slide microscope.

hair shaft or a damaged root, by counting the number of damaged hairs within the first 100 hairs. The same observer carried out all the analyses, with a second observer checking the samples randomly.

\section{Climatic variables of the city of Viçosa}

Environmental temperature data for Viçosa over the study period were obtained from the agrometeorological automatic data collection platform at the Center for Weather Forecast and Climatic Studies, of the National Institute for Space Research, located at the campus of the Federal University of Viçosa, Viçosa, Minas Gerais. For simplicity of comparison with the hair cycle information, the year was divided into two main seasons: hot season, when the monthly environmental temperature was higher than the annual average; and cold season, when it was lower than this average. It is largely accepted that there are not four clearly defined seasons in most parts of Brazil, as observed in temperate climate countries. The mean environmental temperature in the city of Viçosa during the period of study was $19.2^{\circ} \mathrm{C}( \pm 3.1)$, and the mean photoperiod duration was $12.1 \mathrm{~h}( \pm 0.9)$ (Table 1). The hot season extended from October 2005 to April 2006 , and the cold from July to September 2005 and May to June 2006, creating a cold-hot-cold pattern throughout the study. The monthly percentages of anagen and telogen hairs were collated during each period (cold and hot months) and statistically analysed to establish any climatic influence on the hair cycle. The monthly photoperiod duration was calculated according to the equation below ${ }^{15}$ for the latitude estimated at $20^{\circ} 45^{\prime}$ for the city of Viçosa.

$N=[2 / 15] \cdot\left[0,83^{\circ}+\operatorname{arc} \cdot \cos (-\operatorname{tg} \phi \cdot \operatorname{tg} \delta)\right]$, where: $N=$ photoperiod; $\phi=$ latitude; $\delta=$ solar declination.

\section{Statistical analysis}

Since catagen hairs were classed with the telogen hairs, the number of telogen hairs was therefore always equal to 100 minus the number of anagen hairs. The alternative hypotheses that the breeds studied have different numbers of hair in the telogen phase at the same time (month) and that in a given breed the hair numbers in each cycle phase differ with season (hot and cold) were tested.

To identify the behaviour of the hair cycle in dogs with different pelage, the percentage of telogen and anagen hairs among the groups was compared monthly using one-way analysis of variance (ANOVA) complemented with the Tukey test. ${ }^{16}$ Although the results for anagen values were equal to 100 minus telogen, both statistical analyses were performed. To identify the numerical variations in the different phases of the hair cycle in the hot and cold seasons, the means of telogen and anagen hairs of each study group in each season were compared using the one-way ANOVA. ${ }^{16}$

Table 1. Mean monthly and annual values of environmental temperature $\left({ }^{\circ} \mathrm{C}\right)$ and photoperiod duration (hours) in the city of Viçosa, Minas Gerais, between July 2005 and June 2006

\begin{tabular}{|c|c|c|c|c|c|c|c|c|c|c|c|c|c|}
\hline Climatic variable & Jul & Aug & Sep & Oct & Nov & Dec & Jan & Feb & Mar & Apr & May & Jun & $\begin{array}{l}\text { Annual mean and } \\
\text { standard deviation }\end{array}$ \\
\hline Environmental temperature $\left({ }^{\circ} \mathrm{C}\right)$ & 14.7 & 16.7 & 18.6 & 20.3 & 20.2 & 20.5 & 23.1 & 23.1 & 22.1 & 21.2 & 16.1 & 14.3 & $19.2 \pm 3.1$ \\
\hline Photoperiod (hours) & 11.0 & 11.4 & 12.0 & 12.6 & 13.1 & 13.3 & 13.2 & 12.8 & 12.2 & 11.6 & 11.1 & 10.9 & $12.1 \pm 0.9$ \\
\hline
\end{tabular}

Months in italics refer to the cold season, and months in normal text the hot season. 
Figure 2. Mean number of telogen hairs for the three groups, over the period between July 2005 and June 2006. Vertical bars indicate standard deviation. ${ }^{*}$ Indicates a significant difference between groups $(P<0.05)$. The boxer group presented $n=5$ in 10 months and the schnauzer possessed $n=4$ in 5 months.

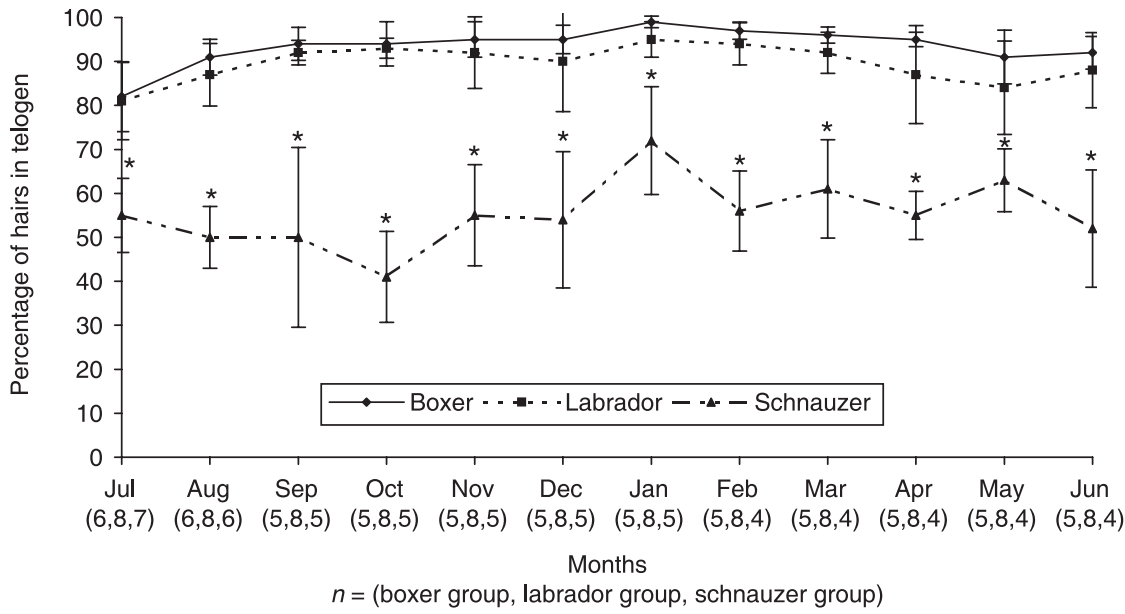

Pearson's correlation was used to evaluate the relationship between hair number variation in the cycle phases and the variation in environmental temperature and with the photoperiod fluctuation. ${ }^{16}$

All statistical tests were performed at $95 \%$ reliability $(P<0.05)$. The analyses of variance were carried out using Microsoft Office Excel 2003 software, the Tukey test using Graphpad InStat, and the Pearson's correlation using BioEstat 3.0.

\section{Results}

Seventeen of the 21 dogs were observed for the entire study period. Only partial data were obtained from one boxer and three schnauzers because the owners ceased to collaborate. Eight labradors, five boxers and four schnauzers were followed for the entire study period. According to the literature, ${ }^{17}$ these withdrawals had no negative influence on the statistical power because in the months containing the lowest number of animals in each group, the error degree of freedom was 14, whereas the minimum value that can be used for this analysis is 10 .

\section{Monthly variations in telogen and anagen hair numbers in the three breeds (BG, LG, and SG)}

In the SG, a significantly lower percentage of telogen hairs and a higher percentage of anagen hairs were always observed when compared to the BG and LG. The percentage of telogen hairs in the latter two groups did not differ statistically at any time over the study period (Fig. 2). The annual means of telogen hairs were $93 \%( \pm 4.3)$ for the BG animals, 90\% ( \pm 4.3 ) for the $L G$ and $55.3 \%( \pm 7.7)$ for the SG. The annual means of anagen hairs were $7 \%$ $( \pm 4.3)$ for the BG animals, $10 \%( \pm 4.3)$ for the $L G$ and $44.5 \%( \pm 8.1)$ for the SG.

The percentage of hairs in telogen, anagen and hairs with damaged or absent roots in $B G$ and $L G$ animals differed in the hot and cold seasons, i.e. the number of telogen hairs was statistically higher in the hot season and lower in the cold season, and the reciprocal was noted for the anagen hairs (the number of anagen hairs was statistically higher in the cold season and is lower in the hot season) for BG and LG animals. However, it was not observed among SG animals (Tables 2 and 3). The percentage of damaged hairs was statistically higher during cold months for the BG and $L G$ animals. There was no difference in the number of damaged hairs for the SG animals (Table 4).
Table 2. Mean and standard deviation of the percentage of telogen hairs, for the breeds studied, in the different seasons (hot and cold). In September 2005 to June 2006 the number of dogs $(n)$ in the boxer group was five; in February 2006 to June 2006 the number of dogs ( $n$ ) in the schnauzer group was four

\begin{tabular}{lll}
\hline & Hairs in telogen & \\
\cline { 2 - 3 } & $\begin{array}{l}\text { Mean percentage and } \\
\text { standard deviation } \\
\text { in hot season }\end{array}$ & $\begin{array}{l}\text { Mean percentage and } \\
\text { standard deviation } \\
\text { in cold season } \\
\left(\text { below } 19.2^{\circ} \mathrm{C}\right)\end{array}$ \\
Groups (n) & $96^{*} \pm 3.1$ & $\left.92^{\circ} \mathrm{C}\right)$ \\
\hline Boxer (6) & $92^{*} \pm 7.5$ & $86^{*} \pm 6.1$ \\
Labrador (8) & $56 \pm 13.7$ & $54 \pm 11.7$ \\
Schnauzer (7) & 56.5
\end{tabular}

Means within rows followed by asterisks $\left({ }^{*}\right)$ are significantly different between the animals of the same group when compared in the different seasons $(P<0.05)$.

Table 3. Mean and standard deviation of percentage of anagen hairs, for the breeds studied, in the different seasons (hot and cold) of the year. In September 2005 to June 2006 the number of dogs $(n)$ in the boxer group was five; in February 2006 to June 2006 the number of dogs $(n)$ in the schnauzer group was four

\begin{tabular}{|c|c|c|}
\hline \multirow[b]{2}{*}{ Groups (n) } & \multicolumn{2}{|l|}{ Hairs in anagen } \\
\hline & $\begin{array}{l}\text { Mean percentage and } \\
\text { standard deviation } \\
\text { in hot season } \\
\text { (above } 19.2^{\circ} \mathrm{C} \text { ) }\end{array}$ & $\begin{array}{l}\text { Mean percentage and } \\
\text { standard deviation } \\
\text { in cold season } \\
\text { (below } 19.2^{\circ} \mathrm{C} \text { ) }\end{array}$ \\
\hline Boxer (6) & $4^{*} \pm 3.1$ & $9^{*} \pm 5.9$ \\
\hline Labrador (8) & $8^{*} \pm 7.5$ & $14^{*} \pm 8.5$ \\
\hline Schnauzer (7) & $43 \pm 13.7$ & $46 \pm 11.7$ \\
\hline
\end{tabular}

Means within rows followed by asterisks $\left({ }^{*}\right)$ are significantly different between the animals of the same group when compared in the different seasons $(P<0.05)$.

A distinct positive correlation was found between the variations in the environmental temperature and photoperiod with the number of telogen hairs for BG and LG animals. Conversely, in these groups, a distinct negative correlation was observed between the variations of environmental temperature and the photoperiod with the number of anagen hairs in these animals (Figs 3 and 4). Boxer and labrador dogs had an increase in anagen and in telogen hairs during the coldest and hottest months of the year, 
Table 4. Mean and standard deviation of percentage of hairs with damaged or absent roots, in the different seasons (hot and cold) of the year. In September 2005 to June 2006 the number of dogs $(n)$ in the boxer group was five; in February 2006 to June 2006 the number of dogs $(n)$ in the schnauzer group was four

\begin{tabular}{lll}
\hline & \multicolumn{2}{l}{ Hairs with damaged or absent roots } \\
\cline { 2 - 3 } & $\begin{array}{l}\text { Mean percentage and } \\
\text { standard deviation } \\
\text { in hot season }\end{array}$ & $\begin{array}{l}\text { Mean percentage and } \\
\text { standard deviation }\end{array}$ \\
in cold season \\
Groups ( $n)$ & $\left(\right.$ above $\left.19.2^{\circ} \mathrm{C}\right)$ & (below $19.2^{\circ} \mathrm{C}$ ) \\
\hline Boxer (6) & $11^{*} \pm 6.8$ & $16^{*} \pm 11.2$ \\
Labrador (8) & $14^{*} \pm 7.8$ & $21^{*} \pm 8.6$ \\
Schnauzer (5) & $12 \pm 5.8$ & $14 \pm 5.7$ \\
\hline
\end{tabular}

Means within rows followed by asterisks $\left({ }^{*}\right)$ are significantly different between the animals of the same group when compared in the different seasons $(P<0.05)$. respectively. Telogen hair number increased with elevated environmental temperature and longer photoperiod and the opposite occurred with anagen hairs for the BG and LG animals. The variation in the environmental temperature had a stronger association than the photoperiod in the group of boxers. However, these influences were essentially the same in the labrador group. There was no correlation between the variation in environmental temperature $(r=0.29$ in the telogen hairs and $r=-0.32$ in the anagen hairs) and photoperiod ( $r=0.16$ in the telogen hairs and $r=-0.20$ in the anagen hairs) with the phase of the hair cycle in SG animals.

\section{Discussion}

The photoperiod duration in the tropical climate of Viçosa (latitude $20^{\circ} 45^{\prime} \mathrm{S}$ ) has a low fluctuation (mean $12.1 \mathrm{~h} \pm 0.9$ ),
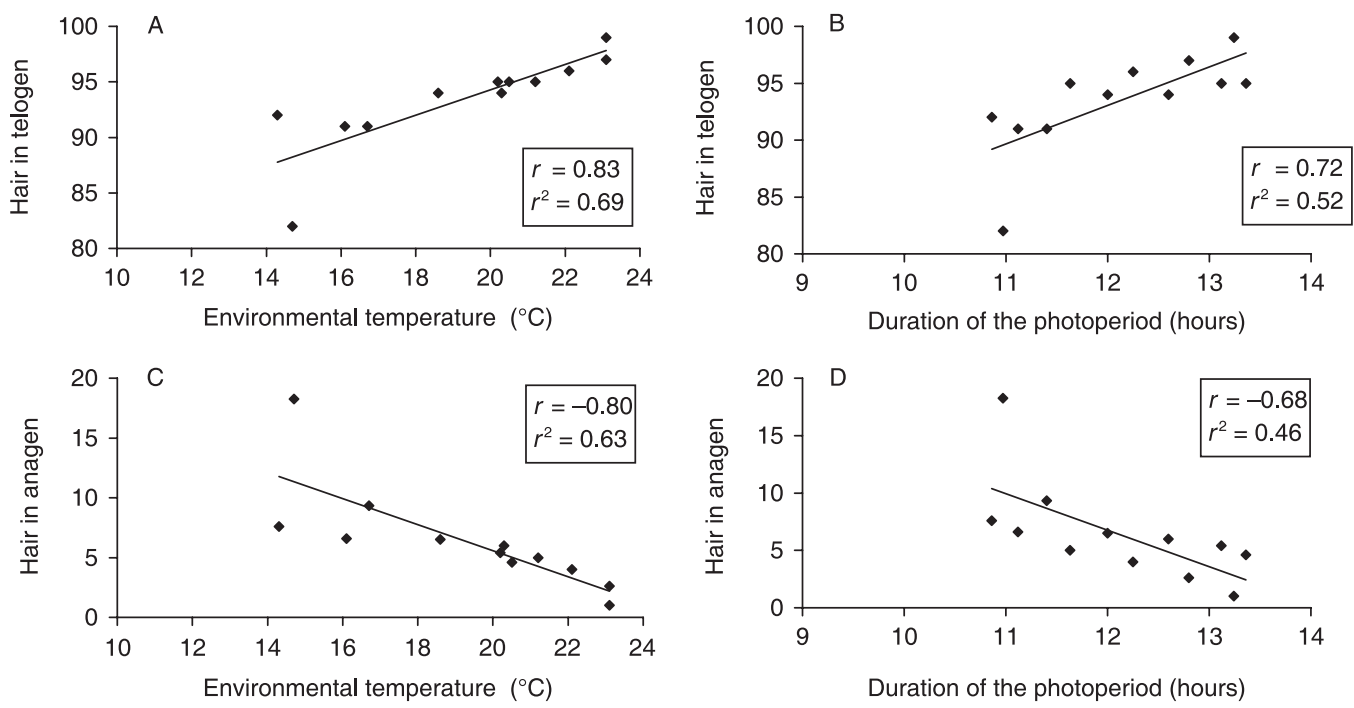

Figure 3. Correlation between the variations in environmental temperature and photoperiod with the number of telogen hairs (A and $B$ ) and anagen hairs (C and D) in the boxer group ( $n=6)$, during the period of the study between July 2005 and June 2006. ( $r$ ) coefficient of correlation; $\left(r^{2}\right)$ coefficient of determination. The boxer group presented $n=5$ in 10 months (September 2005 to June 2006).
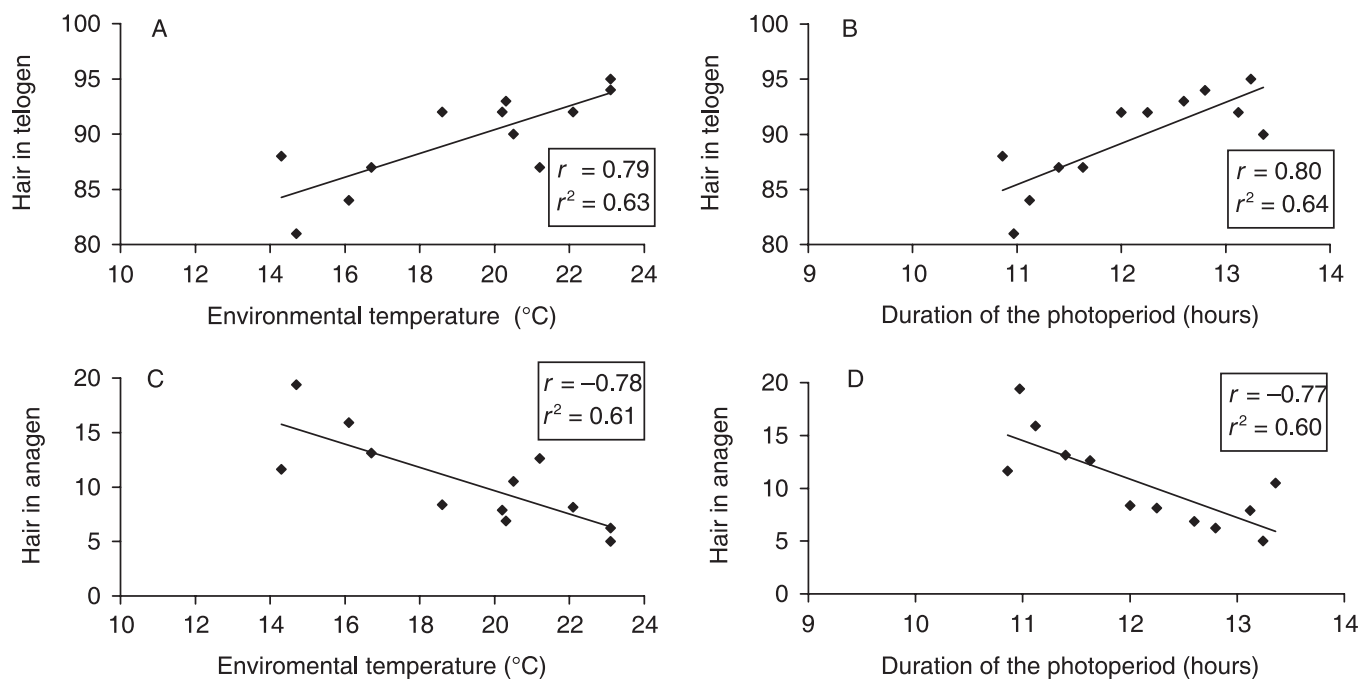

Figure 4. Correlation between variations in the environmental temperature and the photoperiod with the number of telogen hairs (A and $B$ ) and anagen hairs (C and D) in the labrador group $(n=8)$, during the period of study between July 2005 and June 2006 . ( $r$ ) coefficient of correlation; $\left(r^{2}\right)$ coefficient of determination. 
and the environmental temperature also shows little variation (annual mean of $19.2{ }^{\circ} \mathrm{C} \pm 3.1$ ). Other studies on the cyclic activity of canine hair follicles have been carried out in temperate countries with larger variation in environmental temperature and photoperiod and these occasionally produced conflicting results. $1,5,6,9,10,13$ A number of these studies reported values differing from those of the present work. ${ }^{1,5,9,10,13}$ One study reported the existence of half-yearly anagen and telogen peaks, with the former appearing during the summer and winter months and the latter during the spring and fall. ${ }^{13}$ However, other studies showed that hair follicle activity and hair growth rate are maximum in the summer and minimum in the winter. ${ }^{1,6}$

There was no correlation between the variation in the environmental temperature and photoperiod with the hair cycle phases of the SG group. The supposed prolonged anagen period in this breed could be responsible for the poor correlation with both temperature and photoperiod. Further studies, however, are necessary to elucidate this finding, including studies of other typical anagen breeds. Possibly with a standard hair elimination observed in the Viçosa region, where boxer and labradors probably eliminate hairs during various months of the year, these breeds probably suffer greater influences from variable photoperiods and environmental temperatures. This phenomenon may be related to body temperature control, since in the hot months, the animals of the $B G$ and $L G$ had a reduced hair cover to facilitate heat loss and, conversely during the cold months, the fur was denser to conserve heat.

The group with a long pelage (SG) presented larger numbers of anagen hairs in comparison to the short (BG) and medium-length pelages (LG). This finding agrees with previous reports in which the hair proportion in different cycle phases varies with breed ${ }^{1,18}$ and that the anagen period prevails in breeds that need frequent shearing. ${ }^{9}$

In the $\mathrm{BG}$, the variation in environmental temperature had a larger influence on the variation in the hair cycle than the photoperiod fluctuation, contrasting with reports by other authors, ${ }^{1,6}$ which indicate that the cyclic activity of hair follicles is mainly influenced by the variation in photoperiod and to a smaller degree by that in environmental temperature. These divergences might be explained by the different climatic conditions, where the investigations were carried out, or by a sex characteristic. In the present study, the duration of the photoperiod had little variation over the year, whereas the environmental temperature showed larger variations. Furthermore, the mean temperature in the tropical region is unquestionably higher than in temperate regions. However, these influences were essentially the same in the labrador group. This observation suggests that animals with short pelage may occasionally behave differently from breeds with medium-length pelage. However, it is not possible to generalize to other breeds of short and medium-length pelages without further study.

Hairs with damaged or absent roots could not be placed in any phase of the hair cycle. Previous work suggested that most hairs with damaged or absent bulbs were probably in the anagen phase $e^{5,9}$ because in this phase, the hair follicles are more anchored and are localized deeper in the dermis and even in the hypodermis. ${ }^{19}$ This hypothesis is supported by the finding of a larger number of hairs with broken roots in the $B G$ and $L G$ breeds during the cold months, when larger means of anagen hairs were observed. Although the SG showed the largest number of anagen hairs, the mean of hairs with broken roots was lower than those of the $B G$ and $L G$ animals. The reason for that is unknown, but differences in coat type may be responsible. Further studies on hair follicle morphology and hair shaft resistance, between various breeds, are required to explain these differences.

In conclusion, the results suggest that the active hair follicle cycle in boxer and labrador dogs that reside at an latitude of $20^{\circ} 45^{\prime} \mathrm{S}$, correlates strongly with the variation in environmental temperature and photoperiod. It was also observed that in contrast to the schnauzer breed, there was an increase in the percentage of telogen hairs in the hotter months of the year in boxer and labrador dogs.

\section{Acknowledgements}

The authors acknowledge the generosity of CAPES (Coordenação de Aperfeiçoamento de Pessoal de Nível Superior) for their support in providing a postgraduate grant. They are most grateful to Paula D. Bevilacqua and Fabyano Fonseca e Silva for statistical support, and Lukiya B.S.C. Mata and Jair D.C. Junior for technical support.

\section{References}

1. Scott DW, Miller WH, Griffin CE. Structure and function of the skin. Muller and Kirk's Small Animal Dermatology, 6th edn. Philadelphia, PA: W.B. Saunders, 2001: 1-70.

2. Ross MH, Reith EJ, Romrell LJ. Pele e anexos. In: Ross $M H$, Reith EJ, Romrell LJ, eds. Histologia: Texto e Atlas, 2th edn. São Paulo, Brazil: Panamericana, 1993: 347-78.

3. Breazile JE. The physiology of skin, bone and cartilage. In: Breazile JE, Beames CG, Cardielhac PT et al., eds. Textbook of Veterinary Physiology. Philadelphia, PA: Lea \& Febiger, 1971: 540-56.

4. Calhoun ML, Stinson AW. Tegumento. In: Dellmann H, Brown EM, eds. Histologia Veterinária. Rio de Janeiro, Brazil: Guanabara Koogan, 1982: 360-87

5. Diaz SF, Torres SMF, Dunstan RW et al. The effect of body region on the canine hair cycle as defined by unit area trichogram. Veterinary Dermatology 2004; 15: 225-9.

6. Gunaratnam P, Wilkinson GT. A study of animal hair growth in the dog. Journal of Small Animal Practice 1983; 24: 445-53.

7. Comben N. Observations on the mode of growth of the hair of the dog. The British Veterinary Journal 1951; 107: 231-5

8. Milner Y, Sudnik J, Filippi M et al. Exogen, shedding phase of the hair growth cycle: characterization of a mouse model. The Journal for Investigative Dermatology 2002; 119: 639-44.

9. Diaz SF, Torres SMF, Dunstan RW et al. An analysis of canine hair re-growth after clipping for a surgical procedure. Veterinary Dermatology 2004; 15: 25-30.

10. Hale PA. Periodic hair shedding by a normal bitch. Journal of Small Animal Practice 1982; 23: 345-50.

11. Craven AJ, Ormandy CJ, Robertson FG et al. Prolactin signaling influences the timing mechanism of the hair follicle: analysis of hair growth cycles in prolactina receptor knockout mice. Endocrinology 2001; 142: 2533-9.

12. Lincoln GA, Richardson M. Photo-neuroendocrine control of seasonal cycles in body weight, pelage growth and reproduction: lessons from the HPD sheep model. Comparative Biochemistry and Physiology Part C 1998; 119: 283-94.

13. Al-Bagdadi FA, Titkemeyer CW, Lovell JE. Hair follicle cycle and shedding in male beagle dogs. American Journal of Veterinary Research 1977; 38: 611-6.

14. Scott DW, Miller WH, Griffin CE. Diagnostic methods. Muller and 
Kirk's Small Animal Dermatology, 6th edn. Philadelphia, PA: W.B. Saunders, 2001: 71-206.

15. Agritempo - Sistema de Monitoramento Agrometeorológico. Varejão-Silva MA. Meteorologia e Climatologia VD2 2005. Available at: http://www.agritempo.gov.br/publish/publicacoes/ livros/METEOROLOGIA_E_CLIMATOLOGIA_VD2_Mar_pdf. Accessed September 18, 2007.

16. Callegari-Jacques SM, ed. Bioestatística: Princípios e Aplicações. Porto Alegre, Brazil: Artmed, 2003: 255.
17. Everitt BS, Pickles A, eds. Statistical Aspects of the Design and Analysis of Clinical Trials. London: Imperial College Press, 2004: 340.

18. Arslan SH, Mackenzie CP, Brown R et al. The phase of hair growth in hypothyroidism in the dog. Veterinary Research Communications 1983; 6: 51-8.

19. Al-Bagdadi FA, Titkemeyer CW, Lovell JE. Histology of the hair cycle in male Beagle dogs. American Journal of Veterinary Research 1979; 40: 1734-41.

Résumé l'activité du cycle folliculaire a été extensivement étudiée chez l'homme, le mouton et les animaux de laboratoire, mais peu d'informations sont disponibles chez le chein. Le cycle pilaire est affecté par l'espèce, la race, le sexe et l'état général et également par le climat. Le but de cette étude était d'évaluer I'activité folliculaire dans trois races de chiens à différents types de pelage, dans la ville de Viçosa-MG (latitude $-20^{\circ} 45^{\prime}$ ), au Brésil. Vingt et un mâles Boxer, Labrador et Schnauzer ont été évalués tous les mois par trichographie pendant 12 mois. le pourcentage de poils en anagène et en télogène n'était pas différent entre les Boxers et lesLabradors, mais ces deux races étaient différentes des Schnauzers. Une corrélation significative a été notée entre le cycle folliculaire et la température et la photopériode pour les Boxers et les Labradors. Dans ces races, un grand nombre de poils en télogène a été observé dans les mois les plus chauds, et une augmentation du nombre de poils en anagène pendant les mois les plus froids. Le pourcentage moyen de poils en télogène était de $93 \%, 90 \%$ et $55.3 \%$ pour les Boxer, Labrador et Schnauzer, respectivement.

Resumen La actividad cíclica del pelo se ha estudiado extensivamente en humanos, ovejas y animales de laboratorio, pero existe una falta de información en perros. Además de las diferencias en el crecimiento del pelo relacionadas con la especie, raza, sexo y salud general, el crecimiento está principalmente afectado por las variaciones climáticas. El propósito de este estudio fue evaluar la actividad folicular en tres razas de perros con diferentes tipos de pelo en la ciudad de Viçosa-MG (latitud $-20^{\circ} 45^{\prime}$ ), Brasil. Veintitrés machos de razas Boxer, Labrador y Schnauzer fueron analizados mediante tricogramas mensualmente durante 12 meses consecutivos. El porcentaje de pelos en fase anágena y telógena en los diferentes estados del ciclo folicular no fue significativamente distinto entre Boxers y Labradores, pero ambos fueron diferentes de los perros Schnauzer. Se observó una correlación significativa entre el ciclo folicular y la temperatura ambiental y el fotoperiodo en Boxers y Labradores. Es estas razas se observó un mayor número de pelos en fase telógena durante los meses más calurosos del año, y un incremento en los pelos en fase anágena durante los meses más fríos. El porcentaje medio de pelos en fase telógena fue $93 \%$, 90\% y 55.3\% para las razas Boxer, Labrador y Schnauzer, respectivamente.

Zusammenfassung Beim Menschen, bei Schafen und bei Labortieren wurde die Aktivität des Haarzyklus umfassend untersucht, während bei Hunden die entsprechende Information fehlt. Neben Variationen in Bezug auf Spezies, Rasse, Geschlecht und Allgemeinbefinden, unterliegt das Haarwachstum hauptsächlich klimatischen Variationen. Das Ziel der Studie war es, die Follikelaktivität bei drei Hunderassen mit unterschiedlichen Haartypen in der Stadt Viçosa-MG (Breitengrad $-20^{\circ} 45^{\prime}$ ), Brasilien, zu evaluieren. Einundzwanzig männliche Hunde der Rassen Boxer, Labrador und Schnauzer wurden monatlich für die Dauer von 12 aufeinander folgenden Monaten mittels Trichoskopie untersucht. Der prozentuelle Anteil an telogenen und anagenen Haaren in den unterschiedlichen Stadien des Haarzyklus war bei Boxern und Labradors nicht signifikant verschieden, aber beide unterschieden sich von den Schnauzern. Bei Boxern und Labradors wurde eine signifikante Korrelation zwischen Haarfollikelzyklus, Umgebungstemperatur und Fotoperiode beobachtet. Bei diesen Rassen wurde eine größere Anzahl an telogenen Haaren während der heißesten Monate des Jahres beobachtet und eine Zunahme an anagenen Haaren währen der kältesten Monate. Der durchschnittliche Prozentanteil an telogenen Haaren betrug jeweils 93\%, 90\% und 55.3\% für die Rassen Boxer, Labrador und Schnauzer. 